\title{
Fruit Set in Orange with Phytohormones and Its Relation to Endogenous Levels of $\mathrm{GA}_{3}$
}

\author{
Juan José Galván Luna ${ }^{1}$, Luis Alonso Valdez Aguilar ${ }^{1}$, Andrés Martínez Cano ${ }^{1}$ and Ovidio Salazar Salazar ${ }^{2}$ \\ 1. Departamento de Horticultura, Universidad Autónoma Agraria Antonio Narro, Saltillo 25315, Coahuila, México \\ 2. División de Postgrado, Universidad Autónoma de Tamaulipas, Ciudad Victoria, Tamaulipas, México
}

Received: February 16, 2013 / Accepted: May 16, 2013 / Published: August 30, 2013.

\begin{abstract}
This research work aims to contribute in increasing the fruit set in citrus, given its importance in determining fruit yield. The authors evaluated the effects of phytohormones (auxins, gibberellins and cytokinins) in the mooring and features of orange fruit in cultivars Washington navel and Thomson (Citrus sinensis (L.) Osb.). The experiment was established in a split plot randomized complete block design with five treatments and four replications. Flower tissue samples were stored in liquid $\mathrm{N}$ until the extraction of gibberellins and the identification and quantification of $\mathrm{GA}_{3}$. The results showed statistically significant difference $(P \leq 0.05)$ between treatments in the number of fruits retained $129 \mathrm{~d}$ after flowering and the percentage of final tie. $\mathrm{GA}_{3}$ content ranged, on a dry weight basis, from $1.66 \mathrm{mg} \cdot \mathrm{g}^{-1}$ in the control to $20.79 \mathrm{mg} \cdot \mathrm{g}^{-1}$ in the high dose. The mean dose $\left(32.2 \mathrm{mg} \cdot \mathrm{L}^{-1}\right.$ auxins, gibberellins $32.2 \mathrm{mg} \cdot \mathrm{L}^{-1}$ and $83.2 \mathrm{mg} \cdot \mathrm{L}^{-1}$ cytokinins) caused the largest increase in fruit set.
\end{abstract}

Key words: Orange, Washington navel, Thomson, auxins, gibberellins, cytokinins.

\section{Introduction}

Fruit set result of the conjunction of two factors: an initial stimulus that leads to ovarian growth and their ability to accumulate metabolites and their adequate availability. This availability is critical during the abscission and determines final fruit set. It is the fruit set, and not the factor determining flowering harvesting citrus [1]. The biological activity of gibberellins has been determined by bioassays in lettuce hypocotyl according to their polarity [2] and mass spectrometry and gas chromatography (GC-MS) identification of endogenous gibberellins [3, 4].

In the absence of research about the use of growth regulators in northeast Mexico and the low percentage of fruit set in oranges, the present study was conducted with the objective of evaluating the effects of a complex of natural phytohormones (containing auxins, gibberellins and cytokinins) in the tie, yield

Corresponding author: Juan José Galván Luna, Ph.D., professor, research field: fruit research. E-mail: juan.galvan@uaaan.mx. and fruit quality in two cultivars of orange in the center of the state of Tamaulipas, and to identify and quantify the gibberellic acid forms in order to associate the endogenous content with exogenous applications.

\section{Materials and Methods}

The experiment was conducted from 2004 to 2006 in 15 year-old orange trees of two cultivars: Washington navel and Thomson in an orchard located in Victoria, Tamaulipas, Mexico. The orchard was established on a clayey, calcareous soil (34.9\% carbonate), with a $\mathrm{pH}$ of 8.2 and was equipped with micro spray irrigation; irrigation water of satisfactory quality. The experimental trees were $\mathrm{Zn}$-deficient (14-16 mg. $\left.\mathrm{kg}^{-1}\right)$ and had low concentration of $\mathrm{N}, \mathrm{P}$ and $\mathrm{Mg}\left(2.4,0.1\right.$ and $0.24 \mathrm{mg} \cdot \mathrm{kg}^{-1}$, respectively). Gibberellins were extracted and purified from $1 \mathrm{~g}$ (dry weight) samples placed in an Erlenmeyer flask with $50 \mathrm{~mL}$ methanol (80\%). The sample was frozen for 24 h at $-25{ }^{\circ} \mathrm{C}$, filtered with Wathman \# 1 paper. The 
extraction was repeated twice with methanol (100\%) every $3 \mathrm{~h}$ and $2 \mathrm{~h}$. The filtrates were evaporated in a ball flask $\left(250 \mathrm{~mL}, 50{ }^{\circ} \mathrm{C}\right)$ in rotary evaporator water bath. Gibberellins to purify the impurities are separated, with a clean up column (Pack C 18) using the technique reported by Ramirez et al. [5].

The variables measured were: number of flowers per tree (based on the terminal branches of the four cardinal points, the number of flowers were counted and then multiplied by the number of total branches in the tree), fruit number per tree to determine the final fruit set $(\%)$ and the number of retained fruits (NFR) at $129 \mathrm{~d}$ after flowering (DAF) (initial growth stage of the fruit in which no fruit drop was observed). The experiment was conducted in a randomized complete block split plot design with five treatments (Table 1) and four replications arranged in a split plot. The main plot was the cultivar whereas the small plot contained the five spray treatments. A complex of natural phytohormones "Biozyme TF®" containing auxin (indole acetic acid, $32.2 \mathrm{mg} \cdot \mathrm{L}^{-1}$ ), gibberellins (32.2 $\mathrm{mg} \cdot \mathrm{L}^{-1}$ ), cytokinins (zeatin $83.2 \mathrm{mg} \cdot \mathrm{L}^{-1}$ ) and microelements $(0.12 \% \mathrm{Mn}, 0.37 \% \mathrm{Zn}, 0.49 \% \mathrm{Fe}, 0.14 \%$ $\mathrm{Mg}, 0.30 \% \mathrm{~B}$ and $0.44 \% \mathrm{~S}$ ) was sprayed to the trees.

An analysis of variance and mean comparison test using Tukey procedure $(P \leq 0.05)$ was conducted with SAS [6]. Fruit number data was transformed to square root and the percentage of final berth to inverse sine transformation in order to homogenize variances.

\section{Results and Discussion}

\subsection{Percentage of Fruit Set}

The higher $(P \leq 0.05)$ percentage of final fruit set (Table 2) was obtained with the medium dose and high doses. The number of fruits held at medium to very high doses was higher than $138 \%$ higher than in trees with the control treatment.

\subsection{Polar and Equatorial Diameter}

Fruit set depends on the availability of carbohydrates, not only as a source of nutrients but also as hormonal triggers of processes [7] that make possible the increase in fruit tying. Fruit weight showed no significant effects among the doses of phytohormones (Table 3), however, our results showed that fruit weights were higher than the reported values (200-250 g) by Augustine [1], probably due to the phytohormones applied since auxins are related to the process of rapid growth of the fruit, as reported by Talón et al. [8].

Table 1 Treatments applied to orange trees cultivars Washington navel and Thomson, in the central Tamaulipas.

\begin{tabular}{lcccc}
\hline Treatments & $\begin{array}{l}\text { Auxin } \\
\left(\mathrm{mg} \cdot \mathrm{L}^{-1}\right)\end{array}$ & $\begin{array}{l}\text { Gibberellins } \\
\left(\mathrm{mg} \cdot \mathrm{L}^{-1}\right)\end{array}$ & $\begin{array}{l}\text { Cytokinins } \\
\left(\mathrm{mg} \cdot \mathrm{L}^{-1}\right)\end{array}$ & $\begin{array}{l}\text { Trace } \\
\left(\mathrm{L} \cdot \mathrm{g}^{-1}\right)\end{array}$ \\
\hline Control & 0 & 0 & 0 & 0 \\
Low dose & 1.16 & 1.16 & 41.6 & 9.17 \\
Medium dose & 32.2 & 32.2 & 83.2 & 18.34 \\
High dose & 48.3 & 48.3 & 124.8 & 27.51 \\
Very high dose & 64.4 & 64.4 & 166.4 & 36.68 \\
\hline
\end{tabular}

Table 2 Percentage of final fruit set and number of fruits retained (NFR) in orange Washington navel and Thomson cultivas as affected by the applied doses of phytohormones (mean \pm standard error).

\begin{tabular}{lll}
\hline Dose & $\begin{array}{l}\text { Final fruit set } \\
(\%)\end{array}$ & $\begin{array}{l}\text { NFR } \\
\text { (count) }\end{array}$ \\
\hline Control & $0.40 \pm 0.081 \mathrm{~b}^{\mathrm{z}}$ & $12.38 \pm 2.45 \mathrm{~b}$ \\
Low dose & $0.72 \pm 0.183 \mathrm{~b}$ & $18.63 \pm 1.93 \mathrm{~b}$ \\
Medium dose & $1.22 \pm 0.168 \mathrm{a}$ & $31.75 \pm 3.04 \mathrm{a}$ \\
High dose & $1.15 \pm 0.192 \mathrm{a}$ & $34.50 \pm 4.52 \mathrm{a}$ \\
Very high dose & $0.76 \pm 0.105 \mathrm{~b}$ & $29.50 \pm 3.68 \mathrm{a}$ \\
\hline
\end{tabular}

${ }^{\mathrm{z}}$ means with different letters within each column are statistically different (Tukey, $P<0.05$ ).

The values are the averages of each cultivar and for each dose. 
Table 3 Weight of fruit (PF), polar diameter (PD), shell thickness (GC), degrees brix $\left({ }^{\circ} \mathrm{B}\right)$, $\mathbf{p H}$ and color parameter $\left(\mathrm{b}^{*}\right)$ in orange cultivars Washington Navel (Wn) and Thomson (Th) with the application of auxins, gibberellins and cytokinins.

\begin{tabular}{lllllll}
\hline Cvs & PF $(\mathrm{g})$ & DP $(\mathrm{mm})$ & GC $(\mathrm{mm})$ & ${ }^{\circ} \mathrm{B}$ & $\mathrm{pH}$ & $\mathrm{b}^{*}$ \\
\hline Wn & $326^{\mathrm{z}}$ & $84.58 \mathrm{a}$ & 5.34 & $13.24 \mathrm{a}$ & 4.35 & $59.73 \mathrm{a}$ \\
$\mathrm{Th}$ & 331 & $93.21 \mathrm{~b}$ & 5.37 & $14.49 \mathrm{~b}$ & 4.35 & $58.98 \mathrm{~b}$ \\
\hline
\end{tabular}

${ }^{\mathrm{z}}$ means with different letters within columns are statistically different (Tukey, $P \leq 0.05$ ).

Table 4 Concentration of gibberellic acid $\left(\mathrm{GA}_{3}\right)$ in orange Washington navel with application of plant hormones.

\begin{tabular}{llc}
\hline Dose & $\mathrm{GA}_{3}\left(\mathrm{mg} \cdot \mathrm{mL}^{-1}\right)$ & $\mathrm{GA}_{3}\left(\mathrm{mg} \cdot \mathrm{g}^{-1}\right.$ dry weight $)$ \\
Control & 0.00166 & $1.66 \mathrm{~b}^{\mathrm{z}}$ \\
Low dose & 0.00282 & $2.82 \mathrm{~b}$ \\
Average dose & 0.00192 & $1.92 \mathrm{~b}$ \\
High dose & 0.0207 & $20.79 \mathrm{a}$ \\
Very high dose & 0.00232 & $2.32 \mathrm{~b}$ \\
\hline
\end{tabular}

${ }^{\mathrm{z}}$ means with different superscripts per column are statistically different (Tukey, $P \leq 0.05$ ).

Polar diameter and brix showed significant differences between cultivars, being higher in Thomson than in Washington navel, however, no effects were detected on shell thickness, $\mathrm{pH}$ and $\mathrm{b}^{*}$.

\subsection{Gibberellic Acid Concentration}

Table 4 shows that a high dose of the phytohormones sprayed resulted in the highest content of $\mathrm{GA}_{3}$ in the flowers examined was statistically different $(P \leq 0.01)$ to the control treatment. By linking these results with the fruit set, the doses that showed the largest effects were medium and high doses.

\section{Conclusions}

By applying the mean dose $\left(32.2 \mathrm{mg} \cdot \mathrm{L}^{-1}\right.$ auxins, gibberellins $32.2 \mathrm{mg} \cdot \mathrm{L}^{-1}$ and $83.2 \mathrm{mg} \cdot \mathrm{L}^{-1}$ cytokinins) of the complex of natural phytohormones "Biozyme TF®", the fruit set increased from $0.4 \%$ to $1.22 \%$, which allowed a yield $200 \%$ higher than the control in Washington Navel oranges. The cultivars Washington navel and Thomson showed significant differences among them because the hormone levels applicable as to tie the fruit, number of fruits retained, shell thickness, degrees Brix and $\mathrm{pH}$.

\section{References}

[1] M. Agustí, The citrus in the Valencia region, Technical Developments and Structural Issues, Day Autonomous Community of Valencia, November 26, 2002, p. 14.

[2] J. Guardiola, Regulation of flowering and fruit development: Endogenous factors and exogenous manipulation, Proc. Citrus Int. Soc. 1 (2000) 342-346.

[3] L.N. Mander, D. Camp, L.T. Evans, R.W. King, R.P. Pharis, M. Sherburn, et al., Designer gibberellins: The quest for specific activity, Acta Horticulturae 394 (1995) 45-55.

[4] J. Mehouachi, D.J. Iglesias., F.R. Tadeo, M. Agusti, E. Primo-Millo, M. Talon, The role of leaves in citrus fruitlet abscission: Effects on endogenous gibberellin levels and carbohydrate content, J. Hortic. Sci. Biotech. 75 (1) (2000) 79-85.

[5] R.H. Ramirez, A. Benavides-Mendoza, M. Galvan-Estrada, E.A. Rangel-Lopez, Biologically active gibberellin in floral tissue of apple (Malus domestic Borkh), Revista Chapingo, Serie: Horticultura 3 (2) (2001) 197-201.

[6] SAS Institute, SAS/STAT Version 8.0, SAS Institute Inc. Cary, NC, USA, 2000.

[7] D. Iglesias, F. Tadeo, M.E. Primo, M. Heel, Dependence on carbohydrate september fruit availability in citrus trees, Tree Physiol. 23 (2003)199-204.

[8] M. Talón, F.R. Tadeo, M. Juan, J. Soler, M. Agusti, E. Primo, Improving citrus fruit set by applications of gibberellic acid, Comunitat Valencia Land Magazine 15 (2001) 1-8. 